\title{
Synthesis of N-pivot lariat ethers and their metal ion complexation behavior
}

\author{
Larry D. Bratton, Bozena Strzelbicka, and Richard A. Bartsch* \\ Department of Chemistry and Biochemistry, Texas Tech University, Lubbock, Texas 79409-1061 \\ U. S. A. \\ E-mail: Richard.Bartsch@ttu.edu
}

\begin{abstract}
Dedicated to Professor Henry J. Shine on his $80^{\text {th }}$ birthday
(received 18 June 03; accepted 30 Sept 03; published on the web 10 Oct 03)
\end{abstract}

\begin{abstract}
Five new azacrown ethers substituted on nitrogen with (2-naphthyl)methyl, (2quinolinyl)methyl, and (8-methoxy-2-quinolinyl)methyl groups are synthesized. Their complexation behavior towards a variety of mono- and divalent metal ions is assessed by picrate extraction.
\end{abstract}

Keywords: N-Substituted azacrown ethers, metal ion complexation, solvent extraction

\section{Introduction}

Since the initial publications of C. J. Pedersen on the synthesis of macrocyclic polyethers (crown ethers) and their metal salt complexation behavior, ${ }^{1,2}$ the influence of structural variation within such ligands has received ever-increasing attention. ${ }^{3,4}$ One such structural variation is the replacement of one ether oxygen with nitrogen to give an azacrown ether. ${ }^{5}$ Another is the attachment of a functional side arm to the ligand framework to provide the potential for threedimensional complexation of metal ions. Such armed crown ethers have been designated as lariat ethers. ${ }^{6,7}$ If the side arm attachment site is a carbon atom of the macrocycle, the ligand is called a C-pivot lariat ether. If it is a nitrogen atom of an azacrown ether, the ligand is identified as a Npivot lariat ether.

In other laboratories, efficient syntheses of N-pivot lariat ethers in which phenolic and hydroxyquinoline units are attached to an azacrown ether nitrogen by a methylene group have been developed using the Mannich reaction. ${ }^{8}$ We now report reactions of 2-(bromomethyl)-8methoxyquinoline with azacrown ethers to provide a series N-pivot lariat ethers in which the ring size of the macrocyclic ring is systematically varied from 12-crown-4 to 18-crown-6. Examination of CPK space-filling models suggests that the oxygen of the 8-methoxy substituent 
or/and the quinolinyl nitrogen of the side arm unit could interact with a polyether cavitycomplexed metal ion. To provide insight into these potential interactions, condensation products of aza-15-crown-5 with 2-(bromomethyl)naphthalene and 2-(bromomethyl)quinoline were also prepared. The influence of structural variation within the N-pivot lariat ether upon the efficiency and selectivity of mono- and divalent metal ion complexation was determined by metal picrate extraction.

\section{Results and Discussion}

Synthesis of azacrown ethers substituted with (8-methoxy-2-quinolinyl)methyl side arms began with commercially available 8-hydroxy-2-methylquinoline (1) (Scheme 1). Methylation with iodomethane and $\mathrm{NaH}$ in THF gave 8 -methoxy-2-methylquinoline $(2)^{9}$ in $96 \%$ yield. (Attempts to methylate 1 by phase transfer catalysis ${ }^{10,11}$ did not produce the desired product 2.)

Photochemical bromination of 2 with $\mathrm{N}$-bromosuccinimide in $\mathrm{CCl}_{4}$ gave mostly benzylic monobromination, but also some gem-dibromination product. Column chromatography afforded a $62 \%$ yield of 2-(bromomethyl)-8-methoxyquinoline (3). Changing the reaction solvent to dichloromethane $^{12}$ or methyl formate ${ }^{13}$ did not enhance the yield of 3 .

Reaction of the appropriate azacrown ether ${ }^{14,15}$ with 3 and $\mathrm{Na}_{2} \mathrm{CO}_{3}$ in $\mathrm{MeCN}$ gave the Npivot lariat ethers 4-6 in 68-81\% yields.

To probe the influence of the quinolinyl nitrogen and methoxy groups in the side arm upon metal ion complexation, analogs were prepared (Scheme 2) in which one of these two structural units was missing from the N-substituted aza-15-crown-5 ligand. Photochemical bromination of 2-methylnaphthalene (7) and 2-methylquinoline (8) produced the corresponding bromomethyl compounds $\mathbf{9}^{16}$ and 10. ${ }^{17}$ Condensation with aza-15-crown-5 and $\mathrm{Na}_{2} \mathrm{CO}_{3}$ in $\mathrm{MeCN}$ afforded the $\mathrm{N}$-substituted azacrown ether compounds 11 and $\mathbf{1 2}$ in 98 and 83\% yields, respectively.

New ligands 4-6, 11, and 12 were isolated as oils that tenaciously retained chlorinated hydrocarbon solvents.

Metal ion complexation abilities of the new N-pivot lariat ethers 4-6, 11, and 12 were assessed by picrate extraction. ${ }^{18,19}$ Thus, a $5.0 \mathrm{mM}$ aqueous solution of the metal picrate was extracted with an equal volume of $5.0 \mathrm{mM}$ ligand in deuteriochloroform. By comparison of the $\mathrm{UV}$-visible spectra at the picrate absorption maximum for the organic solution before and after extraction, the percent extraction was calculated. 
<smiles>Cc1ccc2cccc(O)c2n1</smiles>

1<smiles></smiles>

1. $\mathrm{NaH}, \mathrm{THF}$
2. Mel $\longrightarrow$<smiles>COc1cccc2ccc(C)nc12</smiles>

2

$\mathrm{Na}_{2} \mathrm{CO}_{3}, \mathrm{MeCN}$

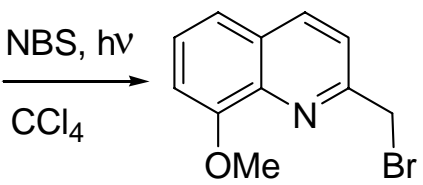

3

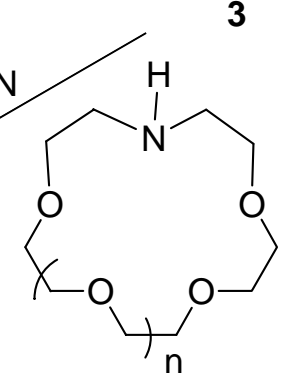

\section{Scheme 1}
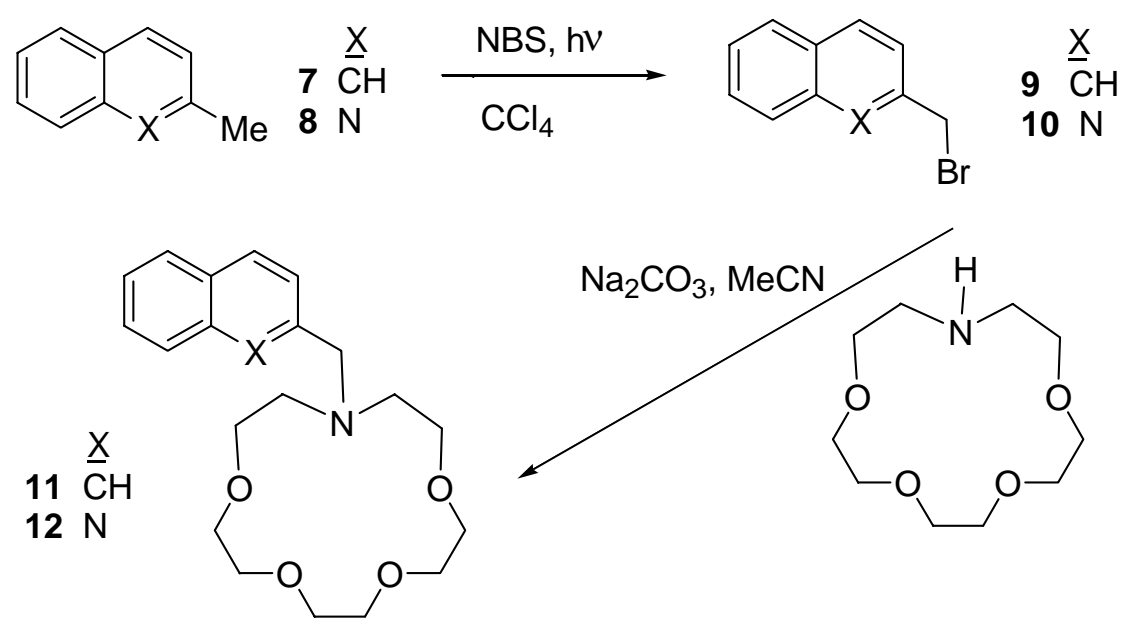

\section{Scheme 2}

N-Pivot lariat ethers 11, 12, and 5 all have aza-15-crown rings, but variation in the aromatic group in the side arm from 2-naphthyl to 2-quinolinyl to 8-methoxy-2-quinolinyl, respectively. Thus, the influence of structural variation in the side arm can be probed with this series of ligands. Results for alkali metal picrate extractions by N-pivot lariat ethers 11, 12, and 5 are presented in Table 1.

Table 1. Extraction of Metal Picrates into Deuteriohloroform by N-Pivot Lariat Ethers 11, 12, and 5

Percent Extraction of Metal Picrate by 


\begin{tabular}{cccc}
\hline $\mathrm{Li}^{+}$ & 3.7 & 4.8 & 8.9 \\
$\mathrm{Na}^{+}$ & 18 & 34 & 46 \\
$\mathrm{~K}^{+}$ & 6.6 & 12 & 46 \\
$\mathrm{Rb}^{+}$ & 5.5 & 6.6 & 21 \\
$\mathrm{Cs}^{+}$ & 4.4 & 4.7 & 10 \\
$\mathrm{Ag}^{+}$ & 90 & 97 & 92 \\
$\mathrm{Tl}^{+}$ & 46 & 84 & 86 \\
$\mathrm{Mg}^{2+}$ & 3.0 & 3.8 & 6.2 \\
$\mathrm{~Pb}^{2+}$ & 20 & 25 & 37 \\
$\mathrm{Cu}^{2+}$ & 49 & 86 & 65 \\
$\mathrm{Zn}^{2+}$ & 81 & 88 & 98 \\
\hline
\end{tabular}

Considering first the data for extraction of hard alkali metal cations, the selectivity order for ligand 11, which has no heteroatom in the side arm, is $\mathrm{Na}^{+}>>\mathrm{K}^{+}>\mathrm{Rb}^{+}>\mathrm{Cs}^{+}, \mathrm{Li}^{+}$. This is consistent with a best match of the cavity size of a 15 -crown- 5 macrocycle by $\mathrm{Na}^{+}$in a nesting complex. ${ }^{20}$ For ligand 12, the aryl group of the side arm has a quinolinyl nitrogen. This structural modification doubles the percent extraction for $\mathrm{Na}^{+}$and $\mathrm{K}^{+}$compared with ligand $\mathbf{1 1}$, while the extraction levels for the remaining alkali metal cations remain nearly the same. This suggests some participation of the quinolinyl nitrogen in a nesting complex ${ }^{20}$ with $\mathrm{Na}^{+}$and a perching complex ${ }^{20}$ with $\mathrm{K}^{+}$, which is too large to fit within the macrocyclic cavity. Compared with ligand 11, incorporation of an 8-methoxy substituent into the side arm in ligand 5 increased the extraction percentages for all of the alkali metal cations with selectivity order of $\mathrm{Na}^{+}, \mathrm{K}^{+}>\mathrm{Rb}^{+}>$ $\mathrm{Cs}^{+}>\mathrm{Li}^{+}$. This indicates participation of the ether oxygen in the side arm with nesting $\mathrm{Li}^{+}$and $\mathrm{Na}^{+}$and perching $\mathrm{K}^{+}, \mathrm{Rb}^{+}$, and $\mathrm{Cs}^{+}$complexes.

For soft $\mathrm{Ag}^{+}$and $\mathrm{Tl}^{+}$, the extraction percentages are much higher than for the hard alkali metal cations. This is consistent with observations reported previously for other azacrown ethers. ${ }^{21}$ For $\mathrm{Ag}^{+}$, the percent extractions is uniformly high (90-97\%) for ligands 11, 12, and 5 and changes only slightly with structural variation in the side arm. On the other hand for $\mathrm{Tl}^{+}$, the percent extraction increases substantially for ligands 12 and 5 compared with $\mathbf{1 1}$ revealing an important interaction of the complexed metal ion with the quinolinyl nitrogen in the side arm.

For the divalent metal ions, weak extraction of $\mathrm{Mg}^{2+}$ is observed with somewhat higher extraction by ligand 5 than by ligands $\mathbf{1 1}$ and 12. Overall higher extraction levels are noted for $\mathrm{Pb}^{2+}$, increasing in the order $\mathbf{1 1}<\mathbf{1 2}<\mathbf{5}$ as heteroatoms are introduced into the aryl group of the side arm. The extraction levels for $\mathrm{Zn}^{2+}$ are even higher, again increasing in the order $\mathbf{1 1}<\mathbf{1 2}<$ 5. For most of the metal ions examined, the addition of an 8-methoxy substituent to the 
quinolinyl group in the side arm increased the extraction percentage. Only for $\mathrm{Cu}^{2+}$ was this structural modification detrimental producing an extraction efficiency order of $\mathbf{1 1}<\mathbf{5}<\mathbf{1 2}$.

N-Pivot lariat ethers 4-6 all have 8-methoxy-2-quinolinyl aryl groups in the side arm, but with systematic variation in the ring size of the azacrown ether ring from 12-crown-4 to 15crown-5 to 18-crown-6, respectively. Results for alkali metal picrate extractions by N-pivot lariat ethers 4-6 are presented in Table 2. (Although the data for ligand 5 was given previously in Table 1, it is presented again for ease of comparison of the effect of ring size variation on the metal ion extraction efficiency.)

Considering the data for extraction of hard alkali metal cations first, the extraction selectivity order for the substituted aza-12-crown-4 and aza-15-crown-5 ligands 4 and 5, respectively, are: $\mathrm{K}^{+} \geq \mathrm{Na}^{+}>\mathrm{Rb}^{+}>\mathrm{Cs}^{+}>\mathrm{Li}^{+}$. This is consistent with the formation of perching complexes with $\mathrm{Na}^{+}-\mathrm{Cs}^{+}$and ligand 4. With ligand 5, a nesting complex is possible for $\mathrm{Na}^{+}$, but perching complexes are required for the larger alkali metal cations. It should be noted that for analogs of $\mathbf{4}$ and 5 with $-\mathrm{CH}_{2} \mathrm{CH}_{2} \mathrm{OCH}_{2} \mathrm{C}_{7} \mathrm{~F}_{15}$ side arms, picrate extraction selectivities for $\mathrm{Li}^{+}$and $\mathrm{Na}^{+}$, respectively, were observed, ${ }^{21}$ as expected if nesting complexes are formed. With the aza-18crown-6 ligand 6, the extraction selectivity order changes to $\mathrm{K}^{+}>\mathrm{Rb}^{+}>\mathrm{Cs}^{+}>\mathrm{Na}^{+}>\mathrm{Li}^{+}$. Based upon the size match with the macrocyclic cavity, $\mathrm{K}^{+}$is expected to exhibit the strongest complexation. A nesting complex with $\mathrm{K}^{+}$is extracted better than the perching complexes formed by $\mathrm{Rb}^{+}$and $\mathrm{Cs}^{+}$.

For the soft monovalent metal ions of $\mathrm{Ag}^{+}$and $\mathrm{Tl}^{+}$, the percent extraction increases with the ring size of the ligand in the order 12 -crown- 4 15-crown-5 $<18$-crown- 6 .

Among the divalent metal ions examined, all three ligands exhibit low extraction of $\mathrm{Mg}^{2+}$. For $\mathrm{Cu}^{2+}$ and $\mathrm{Pb}^{2+}$, the percent extraction increases as the ring size is enlarged. For $\mathrm{Zn}^{2+}$, very high extraction percentages are noted with both the aza-15-crown-5 ligand 5 and the 18-crown-6 ligand 6.

Table 2. Extraction of Metal Picrates into Deuteriochloroform by N-Pivot Lariat Ethers 4, 5, and 6

\begin{tabular}{cccc}
\hline \multicolumn{5}{c}{ Percent Extraction of Metal Picrate by } \\
\hline Metal Ion of Metal Picrate & Ligand 4 & Ligand 5 & Ligand 6 \\
\hline $\mathrm{Li}^{+}$ & 11 & 8.9 & 10 \\
$\mathrm{Na}^{+}$ & 38 & 46 & 18 \\
$\mathrm{~K}^{+}$ & 41 & 46 & 71 \\
$\mathrm{Rb}^{+}$ & 24 & 21 & 60 \\
$\mathrm{Cs}^{+}$ & 15 & 10 & 38 \\
$\mathrm{Ag}^{+}$ & 62 & 92 & 97 \\
$\mathrm{Tl}^{+}$ & 55 & 86 & 94
\end{tabular}




$\begin{array}{llll}\mathrm{Mg}^{2+} & 10 & 6.2 & 6.8 \\ \mathrm{~Pb}^{2+} & 30 & 37 & 63 \\ \mathrm{Cu}^{2+} & 44 & 65 & 72 \\ \mathrm{Zn}^{2+} & 76 & 98 & 94\end{array}$

The results of this screening study reveal that the new N-pivot lariat ethers $\mathbf{5}$ and $\mathbf{6}$ are strong complexing agents for $\mathrm{Ag}^{+}, \mathrm{Tl}^{+}$, and $\mathrm{Zn}^{2+}$.

\section{Experimental Section}

General Procedures. Melting points were determined with either a Mel-Temp or a Fisher-Johns melting point apparatus and are uncorrected. Infrared spectra were recorded with Beckman Acculab 8 or Nicolet MX-S FT-IR spectrometer and are reported in wavenumbers $\left(\mathrm{cm}^{-1}\right)$. ${ }^{1} \mathrm{H}$ NMR spectra were recorded with a Varian EM360 or Bruker AF-200 spectrometer, and chemical shifts are reported in parts per million (ppm) downfield from TMS. ${ }^{13} \mathrm{C}$ NMR spectra were recorded with the Bruker AF-200 spectrometer with chemical shifts (ppm) reported using the center line of the $\mathrm{CDCl}_{3}$ peak as an internal standard. Elemental analysis was performed by Galbraith Laboratories, Inc. of Knoxville, Tennessee. MeCN was purified by distillation from $\mathrm{CaH}_{2}$ and stored over molecular sieves $(5 \AA)$. THF and pentane were purified by distillation from $\mathrm{LiAlH}_{4}$ under nitrogen. $\mathrm{NaH}$ was washed three times with pentane before use. NBromosuccinimide was recrystallized from water ${ }^{22}$ and dried. The azacrown ethers were prepared by reported procedures. ${ }^{14,15}$ All reactions were performed under nitrogen atmosphere. Unless noted otherwise, reagent-grade reactants and solvents from commercial suppliers were used as received.

8-Methoxy-2-methylquinoline (2). To a suspension of $\mathrm{NaH}$ (2.17 g, $54 \mathrm{mmol}, 60 \%$ dispersion in mineral oil) in $150 \mathrm{~mL}$ of THF was added a solution of 8-hydroxy-2-methylquinoline (1) (7.96 g, $50 \mathrm{mmol}$ ) in $150 \mathrm{~mL}$ of THF. The reaction mixture was stirred at room temperature for 2 $\mathrm{h}$ and iodomethane $(7.67 \mathrm{~g}, 54 \mathrm{mmol})$ was added. The reaction mixture was heated at reflux for $72 \mathrm{~h}$ and evaporated in vacuo to give a residue, which was dissolved in $100 \mathrm{~mL}$ of $\mathrm{CH}_{2} \mathrm{Cl}_{2}$. The solution was washed with $5 \%$ aq $\mathrm{NaOH}(3 \mathrm{X} 40 \mathrm{~mL})$ and then with water $(3 \mathrm{X} 40 \mathrm{~mL})$. The washed organic layer was dried $\left(\mathrm{Na}_{2} \mathrm{SO}_{4}\right)$, evaporated in vacuo, and passed through a short silica gel column with $\mathrm{CH}_{2} \mathrm{Cl}_{2}$-EtOAc as eluent to afford $8.28 \mathrm{~g}(96 \%)$ of 2 as a white solid with mp 119.5-121 ${ }^{\circ} \mathrm{C}$ (lit ${ }^{9} \mathrm{mp} 125{ }^{\circ} \mathrm{C}$ ). IR (deposit from $\mathrm{CDCl}_{3}$ solution onto a $\mathrm{NaCl}$ plate): 1100 and $1000(\mathrm{C}-\mathrm{O}) \mathrm{cm}^{-1}$; ${ }^{1} \mathrm{H}$ NMR $\left(\mathrm{CDCl}_{3}\right): \delta 2.78(\mathrm{~s}, 3 \mathrm{H}), 4.07(\mathrm{~s}, 3 \mathrm{H}), 7.02(\mathrm{~d}, \mathrm{~J}=6.9 \mathrm{~Hz}, 1 \mathrm{H}), 7.25-$ $7.50(\mathrm{~m}, 3 \mathrm{H}), 7.99(\mathrm{~d}, \mathrm{~J}=8.3 \mathrm{~Hz}, 1 \mathrm{H})$.

$N$-(8-Methoxy-2-methylquinolinyl) aza-12-crown-4 (4). A solution of 2 (1.00 g, $5.8 \mathrm{mmol})$ and $N$-bromosuccinimide $(1.13 \mathrm{~g}, 6.4 \mathrm{mmol})$ in $200 \mathrm{~mL}$ of $\mathrm{CCl}_{4}$ at reflux was irradiated with a 500-watt tungsten lamp for $2 \mathrm{~h}$. The reaction mixture was filtered in vacuo and the filtrate was 
evaporated in vacuo to give a solid that was chromatographed on silica gel with benzene-EtOAc (4:1) as eluent to provide $0.85 \mathrm{~g}(62 \%) 3$ with $\mathrm{mp} 116-118{ }^{\circ} \mathrm{C}$. IR (deposit from $\mathrm{CDCl}_{3}$ solution on a $\mathrm{NaCl}$ plate): $1100(\mathrm{C}-\mathrm{O}) \mathrm{cm}^{-1} .{ }^{1} \mathrm{H} \mathrm{NMR}\left(\mathrm{CDCl}_{3}\right): \delta 4.06(\mathrm{~s}, 3 \mathrm{H}), 4.79(\mathrm{~s}, 2 \mathrm{H}), 7.06(\mathrm{~d}, \mathrm{~J}=$ $7.4 \mathrm{~Hz}, 1 \mathrm{H}), 7.25-7.55(\mathrm{~m}, 2 \mathrm{H}), 7.63(\mathrm{~d}, \mathrm{~J}=8.5 \mathrm{~Hz}, 1 \mathrm{H}), 8.13(\mathrm{~d}, \mathrm{~J}=8.5 \mathrm{~Hz}, 1 \mathrm{H})$.

A mixture of 3 (1.61 g, $6.8 \mathrm{mmol})$, aza-12-crown-4 (0.80 g, $4.6 \mathrm{mmoles})$, and $\mathrm{Na}_{2} \mathrm{CO}_{3}$ $(1.45 \mathrm{~g}, 13.7 \mathrm{mmol})$ in $100 \mathrm{~mL}$ of $\mathrm{MeCN}$ was refluxed for $4 \mathrm{~d}$. The mixture was filtered in vacuo and the filtrate was evaporated in vacuo to give a residue that was chromatographed on alumina with EtOAc as eluent to give $1.07 \mathrm{~g}(68 \%)$ of $\mathbf{4}$ as a tan oil. IR (neat): 1259, 1124, 1107 (C-O) $\mathrm{cm}^{-1} .{ }^{1} \mathrm{H}$ NMR $\left(\mathrm{CDCl}_{3}\right): \delta 2.85(\mathrm{t}, \mathrm{J}=4.8 \mathrm{~Hz}, 4 \mathrm{H}), 3.40-3.90(\mathrm{~m}, 12 \mathrm{H}), 3.95-4.25(\mathrm{~m}, 5 \mathrm{H}), 6.85-$ $7.15(\mathrm{~m}, 1 \mathrm{H}), 7.20-7.50(\mathrm{~m}, 2 \mathrm{H}), 8.05(\mathrm{~d}, \mathrm{~J}=4.0 \mathrm{~Hz}, 2 \mathrm{H}) .{ }^{13} \mathrm{C} \mathrm{NMR}\left(\mathrm{CDCl}_{3}\right): \delta 54.8,55.9,63.2$, 65.9, 69.4, 69.7, 69.9, 70.1, 70.4, 70.9, 107.5, 119.4, 121.4, 126.0, 128.5, 136.2, 139.2, 154.9, 160.3. Anal. Calcd. for $\mathrm{C}_{19} \mathrm{H}_{26} \mathrm{~N}_{2} \mathrm{O}_{4} \bullet 0.1 \mathrm{CDCl}_{3}$ : C, 64.00; H, 7.31. Found: C, 64.34; H, 7.00.

$\boldsymbol{N}$-(8-Methoxy-2-methylquinolinyl) aza-15-crown-5 (5). Reaction of 3 and aza-15-crown-5 by the procedure described above for the preparation of $\mathbf{4}$ gave an $81 \%$ yield of 5 as a brown oil. IR (neat): $1107(\mathrm{C}-\mathrm{O}) \mathrm{cm}^{-1} .{ }^{1} \mathrm{H}$ NMR $\left(\mathrm{CDCl}_{3}\right): \delta 2.99(\mathrm{t}, \mathrm{J}=6.0 \mathrm{~Hz}, 4 \mathrm{H}), 3.55-3.80(\mathrm{~m}, 16 \mathrm{H}), 4.00-$ $4.25(\mathrm{~m}, 5 \mathrm{H}), 7.03(\mathrm{~d}, \mathrm{~J}=2.1 \mathrm{~Hz}, 1 \mathrm{H}), 7.25-7.50(\mathrm{~m}, 2 \mathrm{H}), 7.89(\mathrm{~d}, \mathrm{~J}=4.5 \mathrm{~Hz}, 1 \mathrm{H}), 8.12(\mathrm{~d}, \mathrm{~J}=$ $8.5 \mathrm{~Hz}, 1 \mathrm{H}) .{ }^{13} \mathrm{C} \mathrm{NMR}\left(\mathrm{CDCl}_{3}\right): \delta 54.9,56.0,63.3,69.9,70.1,70.5,70.9,107.5,119.4,121.4$, 125.9, 128.5, 136.2, 139.3, 154.9, 160.5. Anal. Calcd. for $\mathrm{C}_{21} \mathrm{H}_{30} \mathrm{~N}_{2} \mathrm{O}_{5} \bullet 0.2 \mathrm{CDCl}_{3}$ : C, 61.42; $\mathrm{H}$, 7.29. Found: C, 61.68; H, 7.01.

$\boldsymbol{N}$-(8-Methoxy-2-methylquinolinyl) aza-18-crown-6 (6). Reaction of 3 and aza-18-crown-6 by the procedure described above for the preparation of 4 provided $6(76 \%)$ as a brown oil. IR (neat): $1116(\mathrm{C}-\mathrm{O}) \mathrm{cm}^{-1} .{ }^{1} \mathrm{H} \mathrm{NMR}\left(\mathrm{CDCl}_{3}\right): \delta 2.88(\mathrm{t}, \mathrm{J}=5.9 \mathrm{~Hz}, 4 \mathrm{H}), 3.40-3.90(\mathrm{~m}, 20 \mathrm{H}), 4.00-$ $4.30(\mathrm{~m}, 5 \mathrm{H}), 6.90-7.20(\mathrm{~m}, 1 \mathrm{H}), 7.30-7.60(\mathrm{~m}, 2 \mathrm{H}), 7.75-8.30(\mathrm{~m}, 2 \mathrm{H}) .{ }^{13} \mathrm{C} \mathrm{NMR}\left(\mathrm{CDCl}_{3}\right): \delta$ 54.5, 55.9, 62.7, 69.9, 70.3, 70.5, 70.7, 70.8, 107.5, 119.4, 121.4, 125.9, 128.5, 136.2, 139.3, 154.9, 160.7. Anal. Calcd. for $\mathrm{C}_{23} \mathrm{H}_{34} \mathrm{~N}_{2} \mathrm{O}_{6} \bullet 0.15 \mathrm{CDCl}_{3}$ : C, 61.44; H, 7.57. Found: C, 61.28; H, 7.44 .

$N$-(2-Methylnaphthalene) aza-15-crown-5 (11). Reaction of 2-methylnaphthalene (7) (2.00 g, $14.1 \mathrm{mmol})$ with $\mathrm{N}$-bromosuccinimide $(2.76 \mathrm{~g}, 14.1 \mathrm{mmol})$ by the procedure described above for the preparation of 3 produced $2.77 \mathrm{~g}$ ( $82 \%$ by ${ }^{1} \mathrm{H}$ NMR spectroscopy) of a brown solid that was a mixture of starting material, 2-bromomethylnaphthalene (9), and 2,2-dibromomethylnaphthalene. ${ }^{1} \mathrm{H}$ NMR $\left(\mathrm{CDCl}_{3}\right): \delta 2.35(\mathrm{~s}, 3 \mathrm{H}), 4.40(\mathrm{~s}, 2 \mathrm{H}), 6.55(\mathrm{~s}, 1 \mathrm{H}), 7.15-7.80(\mathrm{~m}, 7 \mathrm{H})$.

Reaction of crude 9 (1.07 g) and aza-15-crown-5 (0.71 g, $3.24 \mathrm{mmol})$ by the procedure described above for the preparation of $\mathbf{4}$ gave $1.14 \mathrm{~g}$ (98\%) of $\mathbf{1 1}$ as a brown oil. IR (neat): 1093 and $1124(\mathrm{C}-\mathrm{O}) \mathrm{cm}^{-1} .{ }^{1} \mathrm{H}$ NMR $\left(\mathrm{CDCl}_{3}\right): \delta 2.80(\mathrm{t}, \mathrm{J}=5.9 \mathrm{~Hz}, 4 \mathrm{H}), 3.45-3.95(\mathrm{~m}, 18 \mathrm{H}), 7.25-$ $8.05(\mathrm{~m}, 7 \mathrm{H}) .{ }^{13} \mathrm{C} \mathrm{NMR}\left(\mathrm{CDCl}_{3}\right): \delta 54.3,60.9,69.9,70.1,70.4,70.9,125.3,125.8,127.1,127.2$, 127.5, 127.6, 127.7, 132.6, 133.2, 137.3. Anal. Calcd. for $\mathrm{C}_{21} \mathrm{H}_{29} \mathrm{NO}_{4} \bullet 0.05 \mathrm{CDCl}_{3}: \mathrm{C}, 69.18 ; \mathrm{H}$, 8.00. Found: C, 68.95; H, 7.98.

$N$-(2-Methylquinoline) aza-15-crown-5 (12). Reaction of 2-methylquinoline (8) (2.00 g, 14.0 $\mathrm{mmol})$ and $\mathrm{N}$-bromosuccinimide $(2.74 \mathrm{~g}, 15.4 \mathrm{mmol})$ by the procedure described above for the 
preparation of 3 produced $1.35 \mathrm{~g}$ (44\%) of 2-(bromomethyl)quinoline (10) as a brown oil. ${ }^{1} \mathrm{H}$ $\operatorname{NMR}\left(\mathrm{CDCl}_{3}\right): \delta 4.65(\mathrm{~s}, 2 \mathrm{H}), 7.20-8.20(\mathrm{~m}, 6 \mathrm{H})$.

Reaction of 10 (1.21 g, $3.6 \mathrm{mmol})$ with aza-15-crown-5 $(0.53 \mathrm{~g}, 2.42 \mathrm{mmol})$ by the procedure described above for the preparation of $\mathbf{4}$ provided $1.08 \mathrm{~g}(83 \%)$ of $\mathbf{1 2}$ as a tan oil. IR (neat): 1124 $(\mathrm{C}-\mathrm{O}) \mathrm{cm}^{-1} .{ }^{1} \mathrm{H}$ NMR $\left(\mathrm{CDCl}_{3}\right): \delta 2.95(\mathrm{t}, \mathrm{J}=5.9 \mathrm{~Hz}, 4 \mathrm{H}), 3.50-3.95(\mathrm{~m}, 16 \mathrm{H}), 4.10(\mathrm{~s}, 2 \mathrm{H}), 7.35-$ $8.30(\mathrm{~m}, 6 \mathrm{H}) .{ }^{13} \mathrm{C} \mathrm{NMR}\left(\mathrm{CDCl}_{3}\right): 54.8,63.1,69.8,70.1,70.5,70.9,121.2,125.9,127.4,127.5$, 128.8, 129.2, 136.2, 147.4, 161.1. Anal. Calcd. for $\mathrm{C}_{20} \mathrm{H}_{28} \mathrm{~N}_{2} \mathrm{O}_{4} \bullet 0.15 \mathrm{CDCl}_{3}: \mathrm{C}, 63.94 ; \mathrm{H}, 7.46$. Found: C, 64.32; H, 7.44.

Picrate extraction into deuteriochloroform. Crown ether solutions $(5.0 \mathrm{mM})$ were prepared in ethanol-free deuteriochloroform. By use of a reported extraction procedure, ${ }^{18,19}$ extractions were conducted by adding $0.50 \mathrm{~mL}$ of a $5.0 \mathrm{mM}$ crown ether solution in $\mathrm{CDCl}_{3}$ to $0.50 \mathrm{~mL}$ of an aqueous $5.0 \mathrm{mM}$ metal picrate solution in a centrifuge tube. The mixture was agitated with a vortex mixer of $60 \mathrm{sec}$. Five identical samples were run concurrently. The mixtures were centrifuged for $10 \mathrm{~min}$ to assure complete layer separation. Precisely measured aliquots were removed from each layer with microsyringes and diluted with MeCN. UV-visible spectra of these solutions were measured in the region of 340-550 nm.

\section{Acknowledgments}

Financial support of this research by the Robert A. Welch Foundation (Grant D-0775 to RAB) is gratefully acknowledged.

\section{References}

1. Pedersen, C. J. J. Am. Chem. Soc. 1967, 89, 7017.

2. Pedersen, C. J. J. Am. Chem. Soc. 1970, 92, 387.

3. Izatt, R. M.; Pawlak, K.; Bradshaw, J. S. Chem. Rev. 1995, 951261.

4. Gokel, G. W., Ed. Comprehensive Supramolecular Chemistry; Elsevier: Oxford, 1996; Vol. 1.

5. Krakowiak, K. E.; Bradshaw, J. S.; Zamecka-Krakowiak,D. J. Chem. Rev. 1989, 89, 929.

6. Gokel, G. W. Chem. Soc. Rev. 1992, 39.

7. Gokel, G. W.; Barbour, L. J.; Ferdani, R.; Hu, J. Acc. Chem. Res. 2002, 35, 878.

8. Habata, Y.; Akabori, S.; Bradshaw, J. S.; Izatt, R. M. Ind. Eng. Chem. Res. 2000, 39, 3465.

9. Doebner, O.; Miller, W. V. Chem. Ber. 1884, 17, 1707.

10. Renault, J.; Mailliet, J. P.; Berlot, J.; Renault, S. C. R. Acad. Sci. Ser. C. 1977, 285, 199.

11. McKillop, A.; Fiaud, J. C.; Hug, R. P. Tetrahedron 1974, 30, 1379.

12. Offerman, W.; Vögtle, F. Angew. Chem. Int. Ed. Engl. 1980, 19, 464.

13. Offerman, W.; Vögtle, F. Synthesis 1977, 272.

14. Maeda, H.; Nakatsuji, Y.; Okahara, M. J. Chem. Soc,. Chem. Comm. 1981, 171, 471. 
15. Gokel, G. W.; Garcia, B. J. Tetrahedron Lett. 1977, 317.

16. A. B. Densham, A. B.; Langston, D. J.; Simpson, A. J. J. Chem. Soc 1952, 5044.

17. Bernard,R.; Abu-Surrah, S. A.; Fawzi, R.; M. Steiman, J. Organomet. Chem. 1995, 497, 73.

18. Sadakane, A.; Iwachido, T.; Toei, K. Bull. Chem. Soc. Jpn. 1976, 48, 60.

19. Moore, S. S.; Tarnowski, T. L.; Newcomb, M.; Cram, D. J. J. Am. Chem. Soc. 1977, 99, 6398.

20. Cram, D. J. Angew. Chem. Int. Ed. Engl. 1986, 25, 1039.

21. Elshani, S.; Kobzar, E.; Bartsch, R. A. Tetrahedron 2000, 56, 3291.

22. Dauben, H. J.; McCoy, L. L. J. Am. Chem. Soc. 1959, 81, 4863. 